\title{
Assessment of clonal fidelity of Tylophora indica (Burm. f.) Merrill "in vitro" plantlets by ISSR molecular markers
}

\author{
Madan Mohan Sharma*, Roop Narayan Verma, Abhijeet Singh and Amla Batra
}

\begin{abstract}
Tylophora indica Burm F. Merrill. is widely used against various diseases owing to the presence an array of medicinally important secondary metabolites. Its stem is bitter, stomachic, stimulates bile secretion, enriches the blood and cures diseases like diabetes, fever, flatulence, hypertension, jaundice, leucorrhoea, urinary disease and upper respiratory tract infection. It is neglected for tissue culture work because of deciduous nature of climbing shrub, facing problems for micropropagation. Hence, in vitro regeneration of complete plantlets was done through indirect organogenesis in Tylophora indica. Calli were produced from in vivo leaves of T. indica on MS medium supplemented with 6-Benzylaminopurine (BAP: $2.0 \mathrm{mg} \mathrm{I}^{-1}$ ) and Indole-3-butyric acid (IBA: $0.5 \mathrm{mg} \mathrm{I}^{-1}$ ). The multiple shoots (12.00 \pm 1.50 ) emerged and elongated on MS medium fortified with Thidiazuron (TDZ: $0.1 \mathrm{mg} \mathrm{I}^{-1}$ ). They were rooted on half strength MS medium having IBA $\left(0.5 \mathrm{mg} \mathrm{I}^{-1}\right)(7.75 \pm 0.25)$ after 20 days of sub-culturing followed by hardening and acclimatization. During indirect regeneration of plants, chances of somaclonal variations may arise. These variations should be identified to produce true to type plants. Plantlets raised through tissue culture were used to validate the clonal fidelity through Inter simple sequence repeat markers (ISSR). Clonal fidelity is a major consideration in commercial micropropagation using in vitro tissue culture methods. During the study, total 71 clear and distinct bands were produced using 6 primers. The banding pattern of each primer was uniform and comparable to mother plant and showed about 93\% homology using un-weighted pair group method with arithmetic averaging (UPGMA). ISSR analysis confirmed the genetic stability of in vitro raised plants.
\end{abstract}

Keywords: Clonal fidelity; ISSR markers; Organogenic calli; Tylophora indica; UPGMA

\section{Introduction}

Tylophora indica Burm F. Merrill., is a perennial and branching climber indigenous to India and native to the plains, forest and hills of southern and eastern India and grows up to an attitude of $1,000 \mathrm{~m}$ in Bengal, Assam, Cachar and Orissa (Ali 2008). It belongs to family Asclepidaceae and is commonly known as Indian Ipecacuanha (Bhavan 1992). Traditionally, it is used as a folk medicine in various regions of India for the treatment of bronchial asthma, bronchitis, allergies, rheumatism and dermatitis (Butani et al. 2007). Besides, it is also a good remedy for anti-psoriasis, seborrheic, anaphylactic, leucopenia and as an inhibitor of the Schultz-Dale reaction (Sarma and Misra 1995). Leaves and roots have medicinal

* Correspondence: drmadanshamra@gmail.com

Plant Biotechnology Laboratory, Department of Botany, University of Rajasthan, Jaipur, India potency and are recognized to show laxative, expectorant, diaphoretic and purgative properties. Tylophorine and tylophorenine are major alkaloids in this plant, which are responsible for a strong anti-inflammatory action (Rao et al. 1971; Gopalakrishnan et al. 1979).

The rate of plant propagation is critical to meet the pharmaceutical demand for Tylophorine, an antiasthamatic drug. A slow propagation rate has been reported in $T$. indica, because of low seed viability, poor germination rate, rare fruit set as well as a small number of propagules (stem cuttings), has restricted the natural dissemination of the plant (Thomas and Philips 2005). In addition, the destruction caused by harvesting the roots and leaves as a source of the drug has threatened the survival of the plant (Faisal and Anis 2007). Thus, in vitro techniques have been applied for large scale production.

\section{Springer}

(c) 2014 Sharma et al.; licensee Springer. This is an Open Access article distributed under the terms of the Creative Commons Attribution License (http://creativecommons.org/licenses/by/4.0), which permits unrestricted use, distribution, and reproduction in any medium, provided the original work is properly credited. 
During plant tissue culture, genotypic variation can be induced at any stage of development of plantlets. Earlier, genetic variations have been confirmed using a variety of molecular markers in Gossypium hirsutum (Jin et al. 2008), Bambusa balcooa (Negi and Saxena 2010), Nothapodytes foetida (Chandrika et al. 2010), Musa spp. (Lu et al. 2011), Oryza sativa (Shan et al. 2012), Spilanthes calva DC (Razaq et al. 2013), Moringa peregrina (Forsk.) (Al Khateeb et al. 2013) and Pilosocereus robinii (Khattaba et al. 2014).

Consequently, a rigorous analysis of genetic stability of the plantlets produced through tissue culture becomes essential. ISSRs are DNA fragments of about 100-3000 bp located between adjacent, oppositely oriented microsatellite regions. They are dispersed throughout the genome and vary in the number of repeat units. To ascertain genetic variations in number as well as sizes of repeat units, we produced in vitro plants of $T$. indica through callus culture and detected genomic variation through reliable, reproducible, low cost and successful molecular markers technology i.e. ISSR which are useful in areas of genetic diversity, phylogenetic studies, gene tagging, genome mapping and evolutionary biology in a wide range of crop species.

The present study was conducted with an aim of ascertaining the genetic uniformity of the tissue culture raised plantlets with respect to mother plant- $T$. indica using ISSRs markers.

\section{Material and methods \\ Plant material}

The experiments were conducted to initiate and produce stock callus through leaf explants for further morphogenetic differentiation. Leaf explants were separately inoculated on MS medium fortified with different concentrations of BAP $\left(0.5-3.5 \mathrm{mg} \mathrm{l}^{-1}\right)$ to initiate callusing. It was followed by subculturing on MS medium containing various concentrations of BAP $\left(0.5-3.5 \mathrm{mg} \mathrm{l}^{-1}\right)$ with IBA $\left(0.025-3.0 \mathrm{mg} \mathrm{l}^{-1}\right)$, 1-Naphthaleneacetic acid (NAA: 0.5-5.0 $\mathrm{mg} \mathrm{l}^{-1}$ ) and 2,4-Dichlorophenoxyacetic acid (2,4-D: $0.5-5.0 \mathrm{mg} \mathrm{l}^{-1}$ ) for the production of stock calli. Subsequently, the small clumps of calli were subcultured for emergence of shoots. In vitro regenerated shoots were rooted on half strength MS medium supplemented with IBA $\left(0.05-0.5 \mathrm{mg} \mathrm{l}^{-1}\right)$ and indole-3acetic acid (IAA: 0.05-0.5 $\mathrm{mg} \mathrm{l}^{-1}$ ). Regenerated plantlets were hardened and acclimatized. These regenerated plantlets were used to procure leaf explants for ISSR analysis. However, four samples of T. indica were used during the studies from Department of Botany, Rajasthan University, Jaipur $\left(T_{1}\right)$ as mother plant, in vitro raised plant produced from $T_{1}$ mother plant $\left(T_{2}\right)$, World Arboretum, Jhalana Dungari, Jaipur $\left(\mathrm{T}_{3}\right)$ and Kulish Smriti Van, Jaipur $\left(\mathrm{T}_{4}\right)$.

\section{Isolation and quantification of genomic DNA}

Healthy leaves washed with running tape water for about $15 \mathrm{~min}$. and wiped with tissue paper used of isolation of genomic DNA. In vitro leaves did not require surface sterilization. Further, $3.0 \mathrm{gm}$ of each leaf sample was homogenized. The homogenized material proceeded by CTAB method (Doyle and Doyle 1990) modified by Sharma et al. (2003). 3.0 gm of leaves were grounded in chilled methanol with autoclaved mortar-pestle. The homogenized material was transferred to $15 \mathrm{ml}$ prewarmed $\left(60^{\circ} \mathrm{C}\right)$ DNA Isolation Buffer (2X CTAB DNA Extraction Buffer-100 mM Tris, $20 \mathrm{mM}$ EDTA, 1.4 M $\mathrm{NaCl}, 2 \% \mathrm{CTAB}$ and $2 \mu \mathrm{l} / \mathrm{ml} \beta$-mercaptoethanol) in capped polypropylene tubes (PP). The clump of homogenized material was suspended using spatula. The content was incubated for $45 \mathrm{~min}$ at $60^{\circ} \mathrm{C}$ and mixed to make solution homogenate by gentle swirling in water bath for 2-3 times. After removing from water bath $15 \mathrm{ml}$ of chloroform: isoamyl alcohol (24:1) was added and mixed by inversion for $30 \mathrm{~min}$ to ensure emulsification of the phases. Content was centrifuged at $15000 \mathrm{rpm}$ for

Table 1 Details of primers, bands and polymorphism in T. indica revealed by 6 primers used in ISSR-PCR

\begin{tabular}{|c|c|c|c|c|c|c|c|}
\hline Primers & Sequences & $\begin{array}{l}\text { Total No. of } \\
\text { bands (a) }\end{array}$ & $\begin{array}{l}\text { Total No. of } \\
\text { Polymorphic } \\
\text { bands (b) }\end{array}$ & $\begin{array}{l}\text { Polymorphism } \\
\left(\mathrm{b} / \mathrm{a}^{*} 100\right)\end{array}$ & $\begin{array}{l}\text { Total No. of } \\
\text { monomorphic } \\
\text { bands (c) }\end{array}$ & $\begin{array}{l}\text { Monomorphism } \\
\left(c / a^{*} 100\right)\end{array}$ & $\begin{array}{l}\text { Average } \\
\text { PIC }\end{array}$ \\
\hline & $\left(5^{\prime} \rightarrow 3^{\prime}\right)$ & & & & & & \\
\hline 807 & AGAGAGAGAGAGAGAGT & 8 & 7 & 87.50 & 1 & 12.50 & 0.5 \\
\hline 812 & GAGAGAGAGAGAGAGAA & 16 & 6 & 37.500 & 10 & 62.50 & 0.82812 \\
\hline 825 & ACACACACACACACACT & 12 & 4 & 33.333 & 8 & 66.66 & 0.875 \\
\hline 827 & ACACACACACACACACC & 11 & 11 & 100.000 & 0 & 0 & 0.56818 \\
\hline 840 & GAGAGAGAGAGAGAGAYT & 5 & 3 & 60.000 & 2 & 40 & 0.7 \\
\hline 846 & CACACACACACACACART & 19 & 10 & 52.632 & 9 & 47.36 & 0.71052 \\
\hline Total & & 71 & 41 & 57.74 & 30 & 42.26 & 0.57 \\
\hline
\end{tabular}

* $=$ Multiply. 
$15 \mathrm{~min}$ at $4^{\circ} \mathrm{C}$ (Remi C 24 plus). Aqueous phase was taken and transferred to another polypropylene tube. Ice cold $6.0 \mathrm{ml}$ of isopropanol was added, gently swirled and kept in deep freezer at $-20^{\circ} \mathrm{C}$ for $30 \mathrm{~min}$ to precipitate DNA. The precipitated DNA-CTAB complex was collected by centrifuging the material at $15000 \mathrm{rpm}$ for
$15 \mathrm{~min}$ at $4^{\circ} \mathrm{C}$. Supernatant was discarded and and washed with $70 \%$ alcohol and kept for 20 min with gentle agitation. The pellet was washed by centrifuging the tube at $10,000 \mathrm{rpm}$ for $10 \mathrm{~min}$ and $4^{\circ} \mathrm{C}$. The liquid was discarded and above step was repeated twice to remove all impurities. The tubes were inverted and drained on a
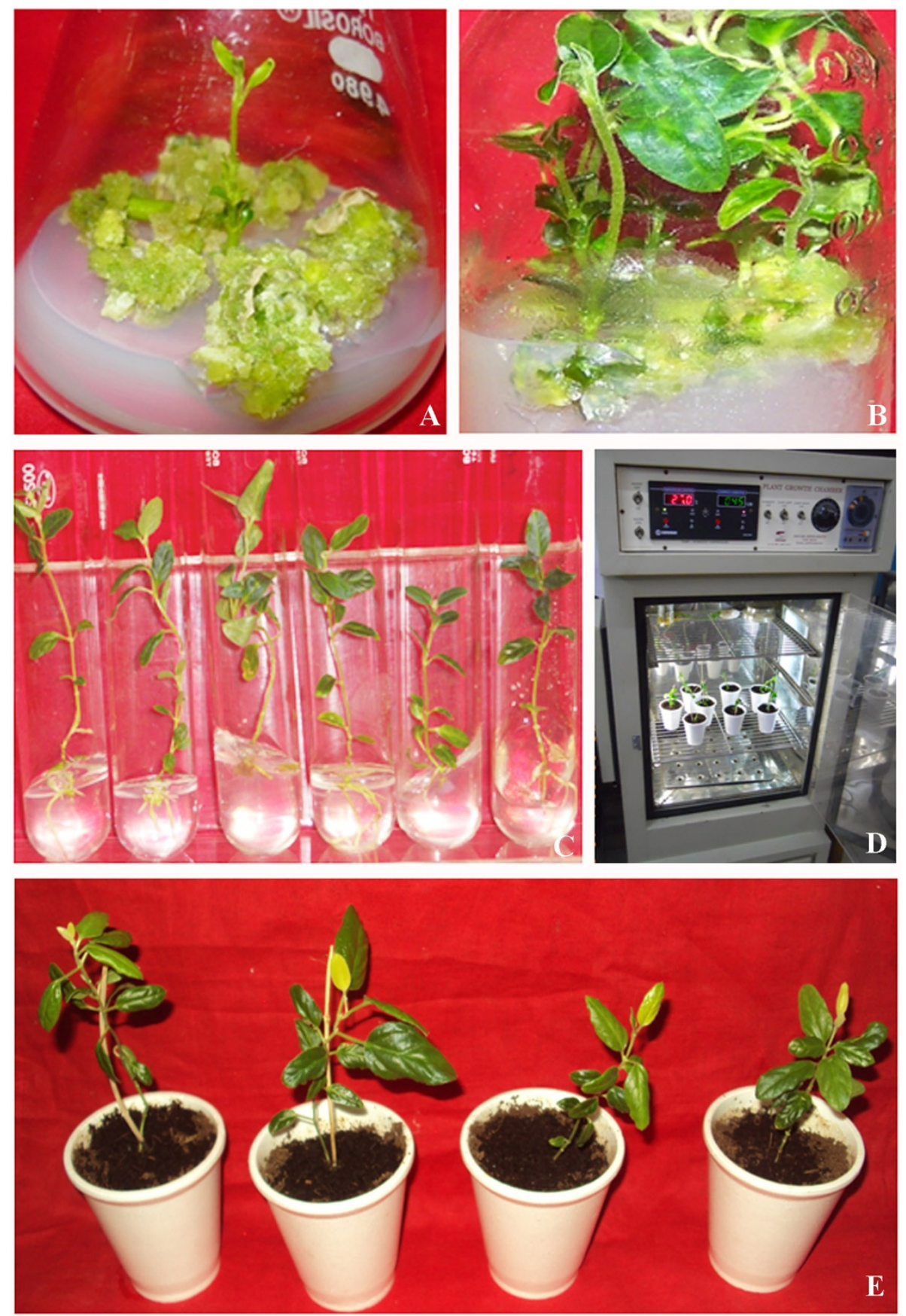

Figure 1 Indirect regeneration of Tylophora indica. A. Callus induced from the leaf and further regeneration of shoots. B. Shoot organogenesis from callus on MS medium along with BAP $\left(2.0 \mathrm{mg} \mathrm{l}^{-1}\right)$ and IBA $\left(0.5 \mathrm{mg} \mathrm{l}^{-1}\right)$. C. In vitro elongation of shoots on TDZ $\left(0.1 \mathrm{mg} \mathrm{l}^{-1}\right)$ and further root induction on $1 / 2$ MS medium with IBA $\left(0.5 \mathrm{mg} \mathrm{I}^{-1}\right)$. D. Hardening in the plant growth chamber. E. Hardened plants in thermocol cups. 
paper towel. The pellet was dried over-night after covering with parafilm with tiny pores. The pellet was redissolved in $100 \mu \mathrm{l}$ of TE buffer by keeping over night at room temperature without agitation.

\section{Purification of DNA}

RNA was removed by treating the sample with DNase free RNase enzyme. Protein including RNase was removed by treating with chloroform: Isoamyl alcohol (24:1). $2.5 \mu \mathrm{l}$ of RNase was added to $0.5 \mathrm{ml}$ of crude DNA extract. It was mixed gently but thoroughly and incubated at $37^{\circ} \mathrm{C}$ for $1 \mathrm{hr}$. After $1 \mathrm{hr}$, a mixture of 0.3 $0.4 \mathrm{ml}$ of chloroform: Isoamyl alcohol (24:1) was added and mixed thoroughly for 15 min till an emulsion was formed. The emulsion was centrifuged at $15000 \mathrm{rpm}$ for $15 \mathrm{~min}$ at $4^{\circ} \mathrm{C}$. Supernatant was taken by avoiding the whitish layer at interface. The DNA was re-precipitated by adding double quantity of ice cold absolute alcohol. To pellet the DNA, the tube was centrifuged for $5 \mathrm{~min}$ at $10,000 \mathrm{rpm}$. The pellet was washed with $70 \%$ alcohol and dried over night. The DNA was re-dissolved in $100 \mu \mathrm{l}$ of TE buffer.

\section{Quantification of DNA}

The quantification of DNA was done at $260 \mathrm{~nm} \&$ $280 \mathrm{~nm}$ UV in spectrophotometer (Optigen 2020 plus UNICAM). The quantitated DNA was diluted to final concentration of $25 \mathrm{ng} / \mu \mathrm{l}$ in TE buffer $(10 \mathrm{mM}$ Tris $\mathrm{Cl}$, $1 \mathrm{mM}$ EDTA, pH 8.0). The diluted DNA was again quantified and confirmed for accurate measurement on $0.8 \%$ agarose gel. All the diluted DNA samples were ranged from $23-27 \mathrm{ng} / \mu \mathrm{l}$.

\section{PCR reactions}

For ISSR analysis, 25 primers (set \# 9) were screened followed by four PCR reactions. The PCR consisted of an initial denaturation step at $94^{\circ} \mathrm{C}$ for $5 \mathrm{~min}, 40$ cycles comprising denaturation cycle at $94^{\circ} \mathrm{C}$ for 30 sec., annealing at $43^{\circ} \mathrm{C}$ for 30 sec., and extension at $72^{\circ} \mathrm{C}$ for $1 \mathrm{~min}$ and a final extension step at $72^{\circ} \mathrm{C}$ for $7 \mathrm{~min}$. followed by hold at $4^{\circ} \mathrm{C}$. PCR amplifications were performed on a DNA thermocylcer (Mycycler, BioRad).

\section{ISSR Primer selection}

25 oligo-nucleotide primers (set \# 9) obtained from the Genomic Chemical Cooperation, University of British Columbia, Vancouver, Canada were screened. Finally, 6 anchored ISSR primers for T. indica (Table 1) were used for the analysis of genetic diversity of 4 genotypes of the plant.

\section{Annealing temperature for ISSR primers}

Annealing temperature for every primer was estimated using gradient PCR and optimum one was selected on the basis of sharpness and reproducibility of bands.

\section{Reproducibility of amplification patterns}

DNA amplifications with each ISSR primer were repeated at least twice to ensure reproducibility. The bands were considered reproducible and scorable only after observing and comparing them in two separate amplifications for each primer. Clear and intense bands were scored while faint bands against background smear were not considered for further analysis.

\section{Results and discussion}

During the experimentation, leaf $\left(3-5 \mathrm{~mm}^{2}\right)$ segments cultured on MS medium augmented with BAP $\left(2.0 \mathrm{mg} \mathrm{l}^{-1}\right)$ and IBA $\left(0.5 \mathrm{mg} \mathrm{l}^{-1}\right)$ proved to be optimum for stock callus production after 3 weeks of inoculation (Figure 1A, B) (Table 2). Similar results were also noticed in Melia azedarach L. (Vila et al. 2004). In contrast, Lin et al. (2009) reported that $\mathrm{Kn}$ is better than BAP to induce

Table 2 Effect of plant growth regulators for callus induction, their further proliferation into multiple shoots through leaf explants

\begin{tabular}{|c|c|c|c|c|c|}
\hline \multicolumn{4}{|c|}{$\begin{array}{l}\text { Plant growth regulators } \\
\left(\mathrm{mg} \mathrm{l}^{-1}\right)\end{array}$} & \multicolumn{2}{|c|}{ Leaf derived calli } \\
\hline BAP & NAA & 2,4-D & IBA & $\%$ response & $\begin{array}{l}\text { Number of shoots/explant } \\
{ }^{*} \text { Mean } \pm \text { S.E. } t_{0.05}\end{array}$ \\
\hline 0.5 & & & & 20 & $2.25 \pm 0.10$ \\
\hline 1.0 & & & & 35 & $2.88 \pm 0.50$ \\
\hline 1.5 & & & & 40 & $3.15 \pm 0.22$ \\
\hline 2.0 & & & & 48 & $6.11 \pm 1.50$ \\
\hline 2.5 & & & & 46 & $5.50 \pm 0.40$ \\
\hline 3.0 & & & & 30 & $4.90 \pm 0.10$ \\
\hline 3.5 & & & & 23 & $3.10 \pm 0.20$ \\
\hline 2.0 & 0.5 & & & 19 & $2.20 \pm 0.10$ \\
\hline 2.0 & 1.0 & & & 22 & $2.45 \pm 0.15$ \\
\hline 2.0 & 2.0 & & & 35 & $2.75 \pm 0.25$ \\
\hline 2.0 & 3.0 & & & 37 & $3.55 \pm 1.50$ \\
\hline 2.0 & 4.0 & & & 28 & $3.40 \pm 0.40$ \\
\hline 2.0 & 5.0 & & & 16 & $2.90 \pm 0.10$ \\
\hline 2.0 & & 0.5 & & 9 & $0.90 \pm 1.05$ \\
\hline 2.0 & & 1.0 & & 12 & $1.15 \pm 0.22$ \\
\hline 2.0 & & 2.0 & & 20 & $1.91 \pm 0.54$ \\
\hline 2.0 & & 3.0 & & 31 & $3.15 \pm 0.42$ \\
\hline 2.0 & & 4.0 & & 24 & $2.56 \pm 0.56$ \\
\hline 2.0 & & 5.0 & & 21 & $2.14 \pm 0.15$ \\
\hline 2.0 & & & 0.025 & 80 & $11.14 \pm 0.90$ \\
\hline 2.0 & & & 0.5 & 95 & $12.00 \pm 1.50$ \\
\hline 2.0 & & & 1.0 & 75 & $9.28 \pm 1.00$ \\
\hline 2.0 & & & 2.0 & 68 & $8.75 \pm 0.80$ \\
\hline 2.0 & & & 3.0 & 55 & $6.45 \pm 0.25$ \\
\hline
\end{tabular}

${ }^{*}=$ Multiply. 
Table 3 Influence of half strength of MS salts along with various auxins on in vitro rooting response

\begin{tabular}{|c|c|c|c|c|}
\hline \multicolumn{2}{|c|}{$\begin{array}{l}\text { Plant growth } \\
\text { regulators } \\
\left(\mathrm{mg} \mathrm{l}^{-1}\right)\end{array}$} & \multirow[t]{2}{*}{$\begin{array}{l}\% \text { response } \\
\text { of rooting }\end{array}$} & \multirow{2}{*}{$\begin{array}{l}\text { No. of roots per } \\
\text { cuttings } \\
{ }^{*} \text { Mean } \pm \text { S.E. } t_{0.05}\end{array}$} & \multirow[t]{2}{*}{$\begin{array}{l}\text { Days taken for } \\
\text { the emergence } \\
\text { of roots }\end{array}$} \\
\hline IBA & IAA & & & \\
\hline 0.05 & & $10 \%$ & $1.10 \pm 0.41$ & $15-16$ \\
\hline 0.1 & & $28 \%$ & $2.25 \pm 0.24$ & 12 \\
\hline 0.2 & & $35 \%$ & $3.14 \pm 0.56$ & $11-12$ \\
\hline 0.3 & & $45 \%$ & $4.45 \pm 0.58$ & 11 \\
\hline 0.4 & & $72 \%$ & $6.65 \pm 0.85$ & 10 \\
\hline \multirow[t]{7}{*}{0.5} & & $85 \%$ & $7.75 \pm 0.25$ & 20 \\
\hline & 0.05 & $5 \%$ & $1.05 \pm 0.10$ & $14-16$ \\
\hline & 0.1 & $15 \%$ & $1.08 \pm 0.51$ & 13 \\
\hline & 0.2 & $25 \%$ & $2.10 \pm 0.65$ & $12-13$ \\
\hline & 0.3 & $45 \%$ & $4.45 \pm 0.52$ & 11 \\
\hline & 0.4 & $35 \%$ & $3.35 \pm 0.54$ & 12 \\
\hline & 0.5 & $22 \%$ & $2.36 \pm 0.26$ & 13 \\
\hline
\end{tabular}

* $=$ Multiply. callusing from leaf explants in case of Ocimum santum. Complete plantlet regeneration via indirect shoot organogenesis has been achieved from the culture of leaf explants. The multiple shoots $(12.00 \pm 1.50)$ were emerged from callus clumps (Figure 1B) (Table 2). At the same time, callus mediated shoot morphogenesis has been well documented in several medicinal plants such as Tylophora indica (Faisal and Anis 2005; Dennis and Boban 2005), Saussurea obvallata (Dhar and Joshi 2005), Euphorbia nivulia (Sunandakumari et al. 2005) and Cassia angustifolia (Agrawal and Sardar 2006). IBA $\left(0.5 \mathrm{mg} \mathrm{l}^{-1}\right)$ incorporated in half strength of MS medium induced optimum rooting $(7.75 \pm 0.25)$ without formation of callus at the cut end of shoots (Table 3 ). However, IAA at its all concentrations used did not produce promising results. In vitro emerged roots on IBA $\left(0.5 \mathrm{mg} \mathrm{l}^{-1}\right)$ were elongated on MS medium supplemented with TDZ $\left(0.1 \mathrm{mg} \mathrm{l}^{-1}\right)$ (Figure 1C). These in vitro regenerated plantlets were hardened and acclimatized in the field conditions with $75 \%$ survival rate (Figure 1D-E). At the same time, IBA also proved to be optimum for in vitro root

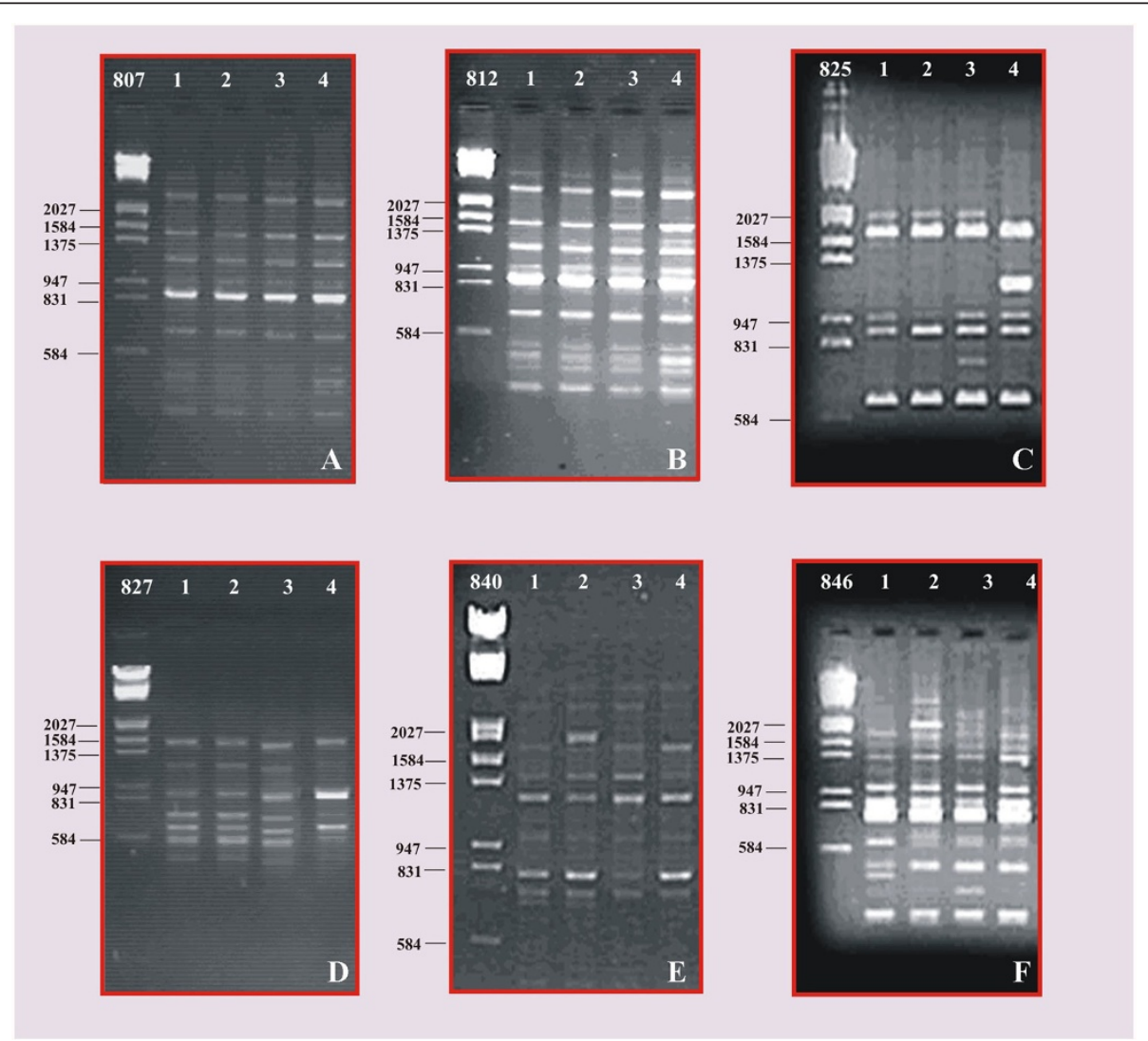

Figure 2 ISSR products of $T$. indica amplified along with marker $\lambda$ DNA/EcoR I-Hind III. A. ISSR primer- 807. B. ISSRprimer- 812 . C. ISSRprimer- 825. D. ISSRprimer- 827. E. ISSRprimer- 840. F. ISSRprimer- 846. 
induction in various plant species such as Phyllanthus amerus Shum. and Thonn (Sen et al. 2009), Murraya koenegii L. Spreng. (Rani et al. 2012), Mentha arvensis (Shahzad et al. 2002) and Hoya wightii spp. Palniensis (Lakshmi et al. 2010). However, in oppugnance to the above results, Dhabhai et al. (2010) in Acacia nilotica and Escutia et al. (2010) in Tigridia pavouia (L.F.) DC found NAA to be optimum for rooting.
Genetic diversity in many plant species can be determined using morphological characteristics; isozyme and DNA based markers. DNA-based markers provide powerful and reliable tools for discerning variations within crop germplasm and for studying evolutionary relationships (Gepts 1993).

ISSR markers are the direct reflection of abundances and distribution of micro satellite repeat in the genome.

Table 4 DNA bands of Tylophora accessions compared with primers

\begin{tabular}{|c|c|c|c|c|c|c|c|c|c|c|c|}
\hline Primer & Size (bp) & $T_{1}$ & $T_{2}$ & $T_{3}$ & $T_{4}$ & Primer & Size (bp) & $T_{1}$ & $T_{2}$ & $T_{3}$ & $\overline{T_{4}}$ \\
\hline \multirow[t]{8}{*}{807} & 676 & 0 & 1 & 1 & 1 & 827 & 302 & 1 & 1 & 1 & 0 \\
\hline & 714 & 1 & 0 & 0 & 0 & & 554 & 1 & 1 & 1 & 0 \\
\hline & 857 & 1 & 1 & 1 & 1 & & 584 & 1 & 1 & 0 & 0 \\
\hline & 1140 & 0 & 0 & 0 & 1 & & 634 & 0 & 0 & 1 & 0 \\
\hline & 1185 & 1 & 1 & 1 & 0 & & 654 & 1 & 1 & 0 & 1 \\
\hline & 1375 & 0 & 0 & 0 & 1 & & 743 & 1 & 1 & 1 & 0 \\
\hline & 1398 & 0 & 0 & 1 & 1 & & 831 & 0 & 0 & 1 & 0 \\
\hline & 1421 & 1 & 0 & 0 & 0 & & 878 & 1 & 1 & 0 & 1 \\
\hline \multirow[t]{16}{*}{812} & 240 & 1 & 1 & 1 & 1 & & 1248 & 1 & 1 & 0 & 0 \\
\hline & 313 & 0 & 1 & 1 & 1 & & 1534 & 0 & 0 & 1 & 0 \\
\hline & 396 & 1 & 1 & 1 & 1 & & 1584 & 1 & 1 & 0 & 1 \\
\hline & 441 & 1 & 1 & 1 & 1 & 840 & 724 & 1 & 1 & 1 & 1 \\
\hline & 662 & 1 & 1 & 1 & 1 & & 802 & 1 & 1 & 0 & 1 \\
\hline & 801 & 1 & 1 & 1 & 1 & & 1201 & 1 & 1 & 1 & 1 \\
\hline & 845 & 1 & 1 & 1 & 1 & & 1225 & 0 & 1 & 1 & 0 \\
\hline & 916 & 0 & 1 & 1 & 1 & & 1904 & 0 & 1 & 0 & 0 \\
\hline & 947 & 1 & 1 & 1 & 1 & 846 & 202 & 1 & 1 & 1 & 1 \\
\hline & 1237 & 0 & 1 & 1 & 1 & & 318 & 0 & 0 & 1 & 0 \\
\hline & 1242 & 1 & 1 & 1 & 1 & & 408 & 1 & 0 & 0 & 0 \\
\hline & 1375 & 0 & 0 & 0 & 1 & & 486 & 1 & 1 & 1 & 1 \\
\hline & 1467 & 1 & 1 & 1 & 1 & & 612 & 1 & 0 & 1 & 1 \\
\hline & 2027 & 0 & 0 & 0 & 1 & & 714 & 1 & 1 & 1 & 1 \\
\hline & 2096 & 0 & 0 & 1 & 1 & & 738 & 1 & 1 & 1 & 1 \\
\hline & 2125 & 1 & 1 & 1 & 1 & & 768 & 1 & 1 & 1 & 1 \\
\hline \multirow[t]{12}{*}{825} & 664 & 1 & 1 & 1 & 1 & & 794 & 1 & 1 & 1 & 1 \\
\hline & 685 & 1 & 1 & 1 & 1 & & 831 & 1 & 1 & 1 & 1 \\
\hline & 696 & 1 & 1 & 1 & 1 & & 862 & 1 & 1 & 1 & 1 \\
\hline & 718 & 0 & 1 & 1 & 1 & & 947 & 0 & 0 & 0 & 1 \\
\hline & 795 & 0 & 0 & 1 & 0 & & 965 & 1 & 1 & 1 & 1 \\
\hline & 872 & 1 & 1 & 1 & 1 & & 1250 & 0 & 1 & 1 & 1 \\
\hline & 947 & 0 & 0 & 1 & 1 & & 1475 & 0 & 0 & 0 & 1 \\
\hline & 1185 & 1 & 1 & 1 & 1 & & 1886 & 0 & 1 & 0 & 0 \\
\hline & 1202 & 1 & 1 & 1 & 1 & & 1898 & 0 & 1 & 0 & 0 \\
\hline & 1676 & 1 & 1 & 1 & 1 & & 2027 & 0 & 1 & 0 & 0 \\
\hline & 1712 & 1 & 1 & 1 & 1 & & 2046 & 0 & 1 & 0 & 0 \\
\hline & 1975 & 1 & 1 & 1 & 0 & & & & & & \\
\hline
\end{tabular}


In the present study, all possible combinations of dinucleotide repeats were included to find out most suitable characterization of the plant genome, because ISSR has already been used in numerous organisms for genetic characterization (Reddy et al. 1999), to assess genetic diversity (Zhang et al. 2006; Wang et al. 2012; Djamila et al. 2012; Yadav et al. 2013; Phulwaria et al. 2013), to identify genetic trait loci (Arcade et al. 2000; Guasmi et al. 2012; Najaphy et al. 2012) and for understanding phylogenetic relationships (Wolfe and Randle 2001; Datwyler and Wolfe 2004; Wu et al. 2005). ISSR amplification is a PCR based method that can rapidly differentiate closely related individuals (Zietkiewicz et al. 1994). This technique involves amplification of DNA segment between two identical microsatellite repeat regions.

Out of 25 primers screened, only 6 primers produced amplification. Finally, 6 anchored ISSR primers were used for the analysis of genetic diversity amongst 4 samples. Six dinucleotide repeat based ISSRs primers (807, $812,825,827,840$, and 846) in $T$. indica were amplified by PCR. AT/TA repeat based ISSRs were not amplified in the study, while maximum band positions and contrasting banding patterns were obtained using CT/CA/ GA/AG/AC repeat based ISSRs (Table 1).

The results of amplified fragments, specific markers for each accession of Tylophora indica using ISSR-PCR analysis were observed and compared with other samples. For each ISSR marker, total amplified bands, total number of monomorphic bands, total number of polymorphic bands, percentage of polymorphic bands, percentage of monomorphic bands and polymorphism information content (PIC) were calculated. Six primers produced a very high degree of polymorphism with a total of 71 reproducible fragments ranging from 3 (primer 840) to 11 fragments (primer 827). The results showed that 30 bands were monomorphic and 41 amplified bands were polymorphic. The highest percentage of polymorphism (100\%) was recorded using the primer 827 , while the lowest percentage (33.33\%) was recorded using primer 825 .

The representative profile of the four accessions and the control with six primers has been shown (Figure 2A-F). The size of polymorphic fragments with six primers varied from 202 to $2125 \mathrm{bp}$ and the number of amplified products ranged from 3 to 11 (Table 4).

Genetic similarities among the four Tylophora accessions were estimated according to the ISSR data. At the same time, Jaccard's coefficient showed that there were two closely related accessions i.e. $\mathrm{T}_{1}$ and $\mathrm{T}_{2}$ with the highest similarity index (93\%). Similarly, the correlation between the time of in vitro culture and the extent of genetic instability has been reported earlier in Picea mariana and P. glauca (Tremblay et al. 1999), Tectona grandis (Gangopadhyay et al. 2003) and Gyposophila paniculate (Rady 2007). Contrary to the present results, some plant species did not show any genetic changes even after maintained for a period of 26 months, 44 months and 4 years, more than 2 years in Curcuma longa (Panda et al. 2007), in Swertia chirayita (Joshi and Dhawan 2007), in almond plantlets (Martins et al. 2004) and in Bambusa balcooa (Chandrika et al. 2010), respectively. At the same time, Jayanthi and Mandal (Jayanthi and Mandal 2001) reported genetic homogeneity and true-to-type nature of the
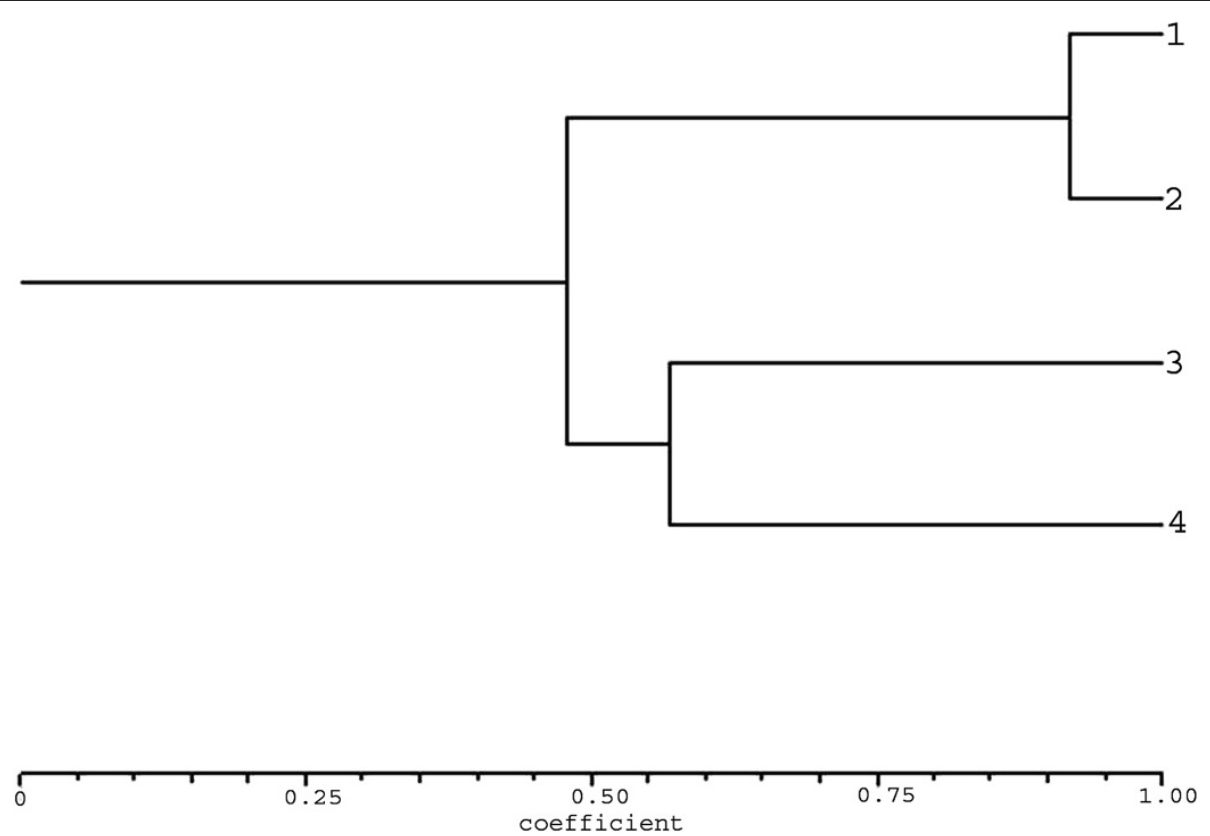

Figure 3 Consensus tree for four Tylophora accession developed on the basis of their banding patterns with ISSR markers. 
plants genetic homogeneity and true-to-type nature of the regenerated through somatic embryogenesis of $T$. indica.

On the other hand, accessions such as $\mathrm{T}_{2}$ with $\mathrm{T}_{3}$ and $\mathrm{T}_{4}$ indicated two most distantly related accessions with low similarity index (57\%). The ISSR binary data matrix was followed to calculate Jaccard's similarity coefficient. Cluster analysis was done via complete linkage method using NTSYS-pc software version 2.02 (Rohlf 2000). Jaccard's similarity coefficients among the all pair-wise combinations of four accessions based on binary data of six ISSR primers ranging from 0.57 to 0.93 was calculated. A dendrogram generated by cluster analysis using UPGMA method based on Jaccard's coefficient indicated the genetic similarity of $93 \%$ among genotypes from in vitro regenerated plantlets through callus organogenesis and the in vivo plant from mother plant thus demonstrating the homogeneity of the tissue culture raised plants (Figure 3).

Hence, it becomes essential to check genetic integrity of the micropropagated plants in order to produce clonally uniform progeny while using tissue culture techniques.

\section{Competing interests}

The authors declare that they have no competing interests.

\section{Authors' contributions}

Perceived and planned the experiments: AB. Executed the experiments: MMS, RNV and AS. Examined the data: AB, RNV. Wrote the paper: MMS, AS, $A B$. All authors read and approved the final manuscript.

\section{Acknowledgement}

Authors are thankful to CSIR for providing financial assistance in the form of major research project [No. 38(1214)/ 09/EMR-II] sanctioned to Prof. Amla Batra, Department of Botany, University of Rajasthan, Jaipur.

Received: 18 March 2014 Accepted: 9 June 2014

Published: 3 August 2014

\section{References}

Agrawal V, Sardar PR (2006) In vitro propagation of Cassiaangustifolia through leaflet and cotyledon derived calli. Biol Plant 50:118-122

Al Khateeb W, Bahar E, Lahham J, Schroeder D, Hussein E (2013) Regeneration and assessment of genetic fidelity of the endangered tree Moringa peregrina (Forsk.) Fiori using Inter Simple Sequence Repeat (ISSR). Physiol Mol Biol Plants 19(1):157-164

Ali M (2008) Pharmacognosy (pharmacognnosy \& phytochemistry), 1st edn. CBS Publisher \& Distributors, New Delhi

Arcade A, Anselin F, Rampant PF, Lesage MC, Paques LE, Prat D (2000) Application of AFLP, RAPD and ISSR markers to genetic mapping of European and Japanese larch. Theor Appl Genet 100:299-307

Bhavan BV (1992) Selected Medicinal Plants of India. Tata Press Bombay, India

Butani AK, Panchal SR, Vyas NY, Khan Y, Kurnar V (2007) Tylophora indica-an ancient anti-asthmatic medicinal plant: a review. Int J Green Pharm 1(2):2-6

Chandrika M, Rai VR, Thoyajaksha (2010) ISSR marker based analysis of micropropagated plantlets of Nothapodytes foetida. Biol Plant 54(3):561-565

Datwyler SL, Wolfe AD (2004) Phylogenetic relationships and morphological evolution in Penstemon subg. Dasanthera (Veronicaceae). Syst Bio 29:165-176

Dennis TT, Boban P (2005) Thidiazuroninduced high-frequency shoot organogenesis from leaf derived callus of a medicinal climber, Tylophora indica (Burm. f.) Merrill. In Vitro Cell Dev - PI 41(2):124-128

Dhabhai K, Sharma MM, Batra A (2010) In vitro clonal propagation of Acacia nilotica (L.) - A nitrogen fixing tree. Researcher 2(3):7-11

Dhar U, Joshi M (2005) Efficient plant regeneration protocol through callus for Saussurea obvallata (DC.) Edgew. (Asteraceae): effect of explant type, age and plant growth regulators. Plant Cell Rep 24(4):195-200
Djamila K, Ammar B, Med M (2012) Using inter simple sequence repeat (ISSR) markers to study genetic polymorphism of pistachio (Pistacia vera L.) in Algeria. Afr J Biotechnol 11(29):7354-7360

Doyle JJ, Doyle JL (1990) Insulation of seedling DNA from fresh tissues. X ray 12:13-15

Escutia JLP, Garica LMV, Fernandiz AMA (2010) In vitro regeneration and genetri fidelity of Tigridia pavouia (L.F.) DC. 13(1):1-7

Faisal M, Anis M (2005) In vitro regeneration and plant establishment of Tylophora indica: Petiole callus culture. In vitro Cell Dev - PI 41(5):511-515

Faisal M, Anis M (2007) Regeneration of plants from alginate encapsulated shoots of Tylophora indica (Burm. f) Merrill, an endangered medicinal plant. J Hort Sci Biotechnol 82:1-4

Gangopadhyay G, Gangopadhyay SB, Poddar R, Gupta S, Mukherjee KK (2003) Micropropagation of Tectona grandis: assessment of genetic fidelity. Biol Plant 46:459-461

Gepts P (1993) The use of molecular and biochemical markers in crop evolution studies. In: Hecht MK (ed) Evolutionary Biology, 27th edn. Plenum Press, New York

Gopalakrishnan C, Shankanarayan D, Nazimudeen SK, Kameswaran L (1979) Effect of tylophorine, a major alkaloid of Tylophora indica, on immunopathological and inflammatory reactions. Indian J Med Res 71:940-948

Guasmi F, Elfalleh W, Hannachi H, Feres K, Touil L, Marzougui N, Triki T, Ferchichi A (2012) The Use of ISSR and RAPD Markers for Genetic Diversity among South Tunisian Barley. Int Schol Res Net ISRN Agron 2012:1-10

Jayanthi M, Mandal PK (2001) Plant regeneration through somatic embryogenesis and rapd analysis of regenerated plants in Tylophora indica (Burm. F. Merrill.). In Vitro Cell Dev Biol Plant 37:576-580

Jin S, Mushke R, Zhu H, Tu L, Lin Z, Zhang Y, Zhang X (2008) Detection of somaclonal variation of cotton (Gossypium hirsutum) using cytogenetics, flow cytometry and molecular markers. Plant Cell Rep 27:1303-1316

Joshi P, Dhawan V (2007) Assessment of genetic fidelity of micropropagated Swertia chirayita plantlets by ISSR marker assay. Biol Plant 51(1):22-26

Khattaba S, El Sherifa F, El-Garhyb HA, Ahmedc S, Ibrahim A (2014) Genetic and phytochemical analysis of the in vitro regenerated Pilosocereus robinii by ISSR, SDS-PAGE and HPLC. Gene 533(1):313-321

Lakshmi SR, Benjamin JHF, Kumar TS, Murthy GVS, Rao MV (2010) In vitro propagation of Hoya wightti sp. Palniensis K.T. Mathew, a highly vulnerable and endemic species of Western Ghats of Tamil Nadu, India. Afri J Biotechnol 9(5):620-627

Lin ZX, Ling APK, Hussein S (2009) Callus induction of Ocimum sanctum and estimation of its total flavonoids content. Asian J of Agri Sci 1(2):55-61

Lu Y, Zhang X, Pu J, Qi Y, Xie Y (2011) Molecular assessment of genetic identity and genetic stability in banana cultivars (Musa spp.) from China using ISSR markers. Aus J Crop Sci 5(1):25-31

Martins M, Sarmento D, Oliveira MM (2004) Genetic stability of micropropagated almond plantlets as assessed by RAPD and ISSR markers. Plant Cell Rep 23:492-496

Najaphy A, Parchin RA, Farshadfar E (2012) Comparison of phenotypic and molecular characterizations of some important wheat cultivars and advanced breeding lines. Aus J Crop Sci 6(2):326-332

Negi D, Saxena S (2010) Ascertaining clonal fidelity of tissue culture raised plants of Bambusa balcooa Roxb. using inter simple sequence repeat markers. New Forests 40:1-8

Panda MK, Mohanty S, Subudhi E, Acharya L, Nayak S (2007) Assessment of genetic stability of micropropagated plants of Curcuma longa L. by cytophotometry and RAPD analyses. Int J Integr Biol 1(3):189-195

Phulwaria M, Rai MK, Shekhawat NS (2013) An improved micropropagation of Arnebia hispidissima (Lehm.) DC. and assessment of genetic fidelity of micropropagated plants using DNA-based molecular markers. Appl Biochem Biotechnol 170(5):1163-1173

Rady MR (2007) In vitro culture of Gyposophila paniculate and random amplified polymorphic DNA analysis of the propagated plants. Biol Plant 50:507-513

Rani U, Sharma MM, Batra A (2012) In vitro plant regeneration from immature seeds of Murraya koenigii (L.) Spreng. Ind J Biotechnol 11(1):108-110

Rao KV, Wilson RA, Cummings B (1971) Alkaloids of Tylophora- New alkaloids of Tylophora indica (Burm) Merrill and Tylophora dalzelii Hook.f. J Pharm Sci 60 (11):1725-1726

Razaq M, Heikrujam M, Chetri SK, Agrawal V (2013) In vitro clonal propagation and genetic fidelity of the regenerants of Spilanthes calva DC. using RAPD and ISSR marker. Physiol Mol Biol Plants 19(2):251-260 
Reddy KD, Nagaraju J, Abraham EG (1999) Genetic characterization of the silkworm Bombyx mori by simple sequence repeat (SSR) anchored PCR. Heredity 83:681-687

Rohlf FJ (2000) NTYSYS-pc ver. 2.02 Numerical taxonomy and multivariate analysis system. Exeter software, Setauket, New York

Sarma VK, Misra KP (1995) Carakokta sarvasrestha vatasamak dravya "rasna" ka adhunik sarveksan. Sachitra Ayurved 48(4):443-446

Sen A, Sharma MM, Grover D, Batra A (2009) In vitro regeneration of Phyllanthus amerus Shum. and Thonn.: an important medicinal plant. Nature 7:110-115

Shahzad A, Gupta P, Siddiqui SA (2002) Micropropagation of Mentha arvensisRole of plant tissue culture in biodiversity conservation and economic development. Gyanodaya Prakashan, Nanital, India

Shan X, Li Y, Tan M, Zhao Q (2012) Tissue culture-induced alteration in cytosine methylation in new rice recombinant inbred lines. Afr J Biotechnol 11(19):4338-4344

Sharma R, Mahla HR, Mohapatra T, Bhargava SC, Sharma MM (2003) Isolating plant genomic DNA without liquid nitrogen. Plant Mol Biol 21(1):43-50

Sunandakumari C, Zhang CL, Martin KP, Slater A, Madhusoodanan PV (2005) Effect of auxins on indirect in vitro morphogenesis and expression of gus $A$ transgene in a lectinacious medicinal plant, Euphorbia nivulia Buch-Ham. In Vitro Cell Dev - PI 41(5):695-699

Thomas DT, Philips B (2005) Thidiazuroninduced high-frequency shoot organogenesis from leaf derived callus of a medicinal climber, Tylophora indica (Burm. f.) Merrill. In Vitro Cell Dev - PI 41(2):124-128

Tremblay L, Levasseur C, Tremblay FM (1999) Frequency of somaclonal variation in plants of black spruce (Picea mariana, Pinaceae) and white spruce ( $P$. glauca, Pinaceae) derived from somatic embryogenesis and identification of some factors involved in genetic instability. Am J Bot 86(10):1373-1381

Vila SK, Rey HY, Mrogiuski LA (2004) Influence of genotype and explant sources on indirect organogenesis by in vitro culture of leaves of Melia azearach L. Biocell 28(1):35-41

Wang XM, Hou XQ, Zhang YQ, Yang R, Feng SF, Li Y, Ren Y (2012) Genetic Diversity of the Endemic and Medicinally Important Plant Rheum officinale as Revealed by Inter-Simpe Sequence Repeat (ISSR) Markers. Int J Mol Sci 13:3900-3915

Wolfe AD, Randle CP (2001) Relationships within and among species of the holoparasitic genus Hyobanche (Orobanchaceae) inferred from ISSR banding patterns and nucleotide sequences. Syst Bot 26:120-130

Wu W, Zheng YL, Chen L, Wei YM, Yang RW, Yan ZH (2005) Evaluation of genetic relationships in the genus Houttuynia Thunb. in China based on RAPD and ISSR markers. Biochem Syst Ecol 33:1141-1157

Yadav K, Aggarwal A, Singh N (2013) Evaluation of genetic fidelity among micropropagated plants of Gloriosa superba L. using DNA-based markers-a potential medicinal plant. Fitoterapia 89:265-270

Zhang XP, Li XH, Qiu YX (2006) Genetic diversity of the endangered species Kirengeshoma palmata (Saxifragaceae) in China. Biochem Syst Ecol 34:38-47

Zietkiewicz E, Rafalski A, Labuda D (1994) Genome fingerprinting by simple sequence repeat (SSR) anchored polymerase chain reaction amplification. Genomics 20:176-183

doi:10.1186/2193-1801-3-400

Cite this article as: Sharma et al:: Assessment of clonal fidelity of Tylophora indica (Burm. f.) Merrill "in vitro" plantlets by ISSR molecular markers. SpringerPlus 2014 3:400.

\section{Submit your manuscript to a SpringerOpen ${ }^{\circ}$ journal and benefit from:}

- Convenient online submission

- Rigorous peer review

- Immediate publication on acceptance

- Open access: articles freely available online

- High visibility within the field

- Retaining the copyright to your article

Submit your next manuscript at $>$ springeropen.com 